Oral Tradition, 18/1 (2003): 79-81

\title{
The Reception of Homer as Oral Poetry
}

\author{
M. D. Usher
}

For me, one of the most interesting directions in oral tradition studies focuses on the reception of Homeric poetry as oral poetry in classical and later antiquity. The topics and materials for study here are wide-ranging. They include the internalization of Homeric poetics by lyric and elegiac poets; "rhapsodic" variation and conflation of lines in authors who quote Homer; the adaptation of Homeric tags in Cynic street sermons; the pastiche form known as the cento; even the re-use of Homeric poetry in magical incantations, to name just a few avenues of investigation.

The question that presents itself is twofold: to what degree were ancient readers and users of Homer influenced by oral habits of composition, and how can we know this? Any answer to this question must employ a basic technique of the oral-formulaic method, namely "how to work backwards" from the form of the texts we possess "so as to learn how they must have been made" (Parry, quoted in Lord 1960:3). And if, as one authority puts it, the linguistic analysis of formulas and themes in verbal art forms "can provide insight into the cognitive processes . . of a prehistoric society and culture" (Watkins 1995:43), it is not unreasonable to suppose that we might be able to recover something of the cognitive processes of Homeric readers in a more historical age by a similar analysis of passages that are tinged by Homeric quotation.

Of particular interest are traces in later authors of the kind of associative thinking that is typical of oral poetic composition. The point of departure here is Marcel Jousse's 1925 study of the mnemotechnics of an oral style, which demonstrated how oral habits of composition persist in literate traditions. Recent work on the cognitive psychology of memory by, e. g., Alan Baddeley (1990) and applied specifically to oral art forms by David Rubin (1995), Elizabeth Minchin (2001), and others has corroborated Jousse's findings. John Foley's reworking (1991) of literary Rezeptionsästhetik for the field of oral tradition studies-what Foley calls "traditional referentiality" or "immanent art"-is another foundational study, as it explains how oral poetic structures (and thus the orally-derived texts 
that were read by ancient readers) convey meaning differently than literary ones. Matthew Clark's fascinating work (1997) on the "deep structure" of Homeric composition is also relevant. Especially important is his discovery (building on the ideas of Michael Nagler, Joseph Russo and others) that nonformulaic patterns of repetition-those that do not necessarily express, in Parry's definition, a given essential idea (for example the collocation and clustering of syntactically unrelated words and phrases)-also serve the Homeric poet as cues for composition.

The proposition that one will find oral residue in later authors is hardly controversial or surprising. If Homeric poetry is indeed a generative system, users of it are bound to show traces of its characteristic features. The majority of ancient Greek and Roman readers were, after all, reared on the recitation of Homer. But demonstrations of this proposition on a caseby-case basis promise to shed light on exactly how the oral/aural aspects of ancient reading affected ancient composition and this awareness, in turn, must affect our interpretations of ancient texts. Thus, in working backwards, we will have come full circle.

University of Vermont

\section{References}

Baddeley 1990

Bakker 1993

Clark 1997

Foley 1991

Jousse 1925
Alan D. Baddeley. Human Memory: Theory and Practice. Boston: Allyn and Bacon.

Egbert J. Bakker. "Activation and Preservation: The Interdependence of Text and Performance in an Oral Tradition." Oral Tradition, 8:5-20.

Matthew Clark. Out of Line: Homeric Composition beyond the Hexameter. Lanham, MD: Rowman and Littlefield.

John Miles Foley. Immanent Art: From Structure to Meaning in Traditional Oral Epic. Bloomington: Indiana University Press.

Marcel M. Jousse. Le Style oral rhythmique et mnémotechnique chez les Verbo-moteurs. [Trans. as The Oral Style by Edgard Sienaert and Richard Whitaker. New York: Garland, 1990]. 
Lord 1960/2000

Miller 1982

Minchin 2001

Nagy 2000

Rubin 1995

Watkins 1995
Albert B. Lord. The Singer of Tales. 2nd ed. 2000 with introduction by Stephen Mitchell and Gregory Nagy. Cambridge, MA: Harvard University Press.

D. Gary Miller. Improvisation, Typology, Culture, and the "The New Orthodoxy": How "Oral" is Homer? Washington, D. C.: University Press of America.

Elizabeth Minchin. Homer and the Resources of Memory: Some Applications of Cognitive Theory to the Iliad and the Odyssey. Oxford: Oxford University Press.

Gregory Nagy. "Epic as Music: Rhapsodic Models of Homer in Plato's Timaeus and Critias." In Plato's Rhapsody and Homer's Music: The Poetics of the Panathenaic Festival in Classical Athens. Washington, D.C.: Center for Hellenic Studies. pp. 36-69.

David C. Rubin. Memory in Oral Traditions: The Cognitive Psychology of Epic, Ballads, and Counting-out Rhymes. Oxford: Oxford University Press.

Calvert Watkins. How to Kill a Dragon: Aspects of IndoEuropean Poetics. Oxford: Oxford University Press. 